\title{
The Myth of Scotland as Nowhere in Particular
}

John Marmysz, College of Marin

\section{Introduction}

Tartanry, Kailyard and Clydesideism are three of the familiar, mythic stereotypes consistently recycled in television shows and films depicting Scots or using Scotland as a setting. As has been observed often enough in the past, these myths offer portrayals of Scotland that are, in many ways, false reifications (Craig 1982; McArthur 1982; Hardy 1990, p. 1-8; Petrie 2000; Oria Gomez 2008; MartinJones 2010; Balkind 2013, p. 5). However, they have also served an important purpose in helping to shape and form the very idea of Scotland as a place that is special and unique from other world locations. In recent times a cinematic countermovement against past Scottish mythologising has appeared - exemplified by such films as Prometheus (2012), The Dark Knight Rises (2012), Perfect Sense (2011), Under the Skin (2013), World War Z(2013) and Cloud Atlas(2013) - that deemphasises Scottish uniqueness, depicting Scotland as a place that is largely indistinct from, or indeed interchangeable with, other locations around the globe. This countermovement also serves a constructive purpose as it helps to emphasise those aspects making Scotland a place much like any other, thus highlighting it as part of the world community. In this article I shall argue that what we see in this new cinematic counter-movement is part of a new Scottish myth in the making: the myth of Scotland as nowhere in particular.

This new myth takes the countryside and cities of Scotland as raw material for the telling of stories having transcultural and transnational interest. In this, Scotland becomes a kind of space or clearing with no particular defining characteristics of its own that might distract from the dramas themselves, thus allowing for the unfolding of narratives that, while they use Scotland as a location, have little if anything to do with things uniquely Scottish. The value of such dramas is that they possess a potentially wide appeal to anyone, anywhere. In trying to understand this phenomenon, I shall draw upon the insights of Martin Heidegger; in particular his discussion of Being as a 'nothing' that underlies and supports the emergence of worlds. I shall argue that Scotland has, in many contemporary films, lost a great deal 
of its exotic appeal by becoming a 'nothing,' or a 'clearing,' much like any other world location. While on the one hand effacement of its uniqueness perhaps leads to the concealment of Scottish distinctiveness, such cinematic depictions also potentially allow for the treatment of more universal issues and concerns. I conclude this article essay with an examination of a number of recent films that embody the myth of Scotland as nowhere in particular. I do not restrict my investigation only to native Scottish productions, but also address patterns found in Hollywood movies that utilise the countryside and cites of Scotland as backdrops, as these films exert a very wide (perhaps the widest) influence on the way that Scotland is conceptualised by audiences across national and cultural boundaries. ${ }^{1}$ They are also the films in which this new myth is often found in its most complete form.

Authors such as Duncan Petrie, Ian Goode, David-Martin Jones, Sarah Neely, Simon Brown, Sarah Street, and Nicola Balkind have previously commented on the emerging 'transcultural' and 'transnational' aspects of Scottish Cinema in which, as Brown writes, we find, 'Scotland itself literally receding into the background,' so as to act as a 'mere location for a universal story'(2011, p. 6). While some critics have argued in a more general context that these sorts of transcultural and transnational themes are the result of the forces of globalisation and an increasing push to market movies to ever wider and more diverse audiences (Herbert 2009; Martin-Jones 2010, p. 37; Royer 2010), the focus of this article is ontological in its approach, not causal. My goal is merely to identify and describe the structure and meaning of the emerging myth of Scotland as nowhere in particular rather than to engage in speculation concerning its causes or its political, cultural, economic, tourist or marketing implications.

\section{Traditional Scottish M yths}

Myths are meaningful stories that help to give shape and context to our understanding of reality. Unlike historical narratives, mythic stories tend to rely heavily on allegory and do not function primarily as instruments for the expression of literal facts. Instead, they operate by means of a symbolic pantheon of characters and images that help us to picture in our minds the overarching nature and significance of the universe, as well as our place within it (Schorer 1968, p. 355). Joseph Campbell 
calls myths 'depersonalised dreams,' (2008, p. 14) emphasising their reliance on symbolism that is, while sometimes manifestly absurd, nonetheless expressive of latent truths concerning real patterns and structures that operate in collective human thinking. With the rise of science in ancient Greece, friction developed between mythmakers and those demanding that symbolism, metaphor and storytelling be set aside in favour of the careful observation of nature and its systematic, logical explanation. Nevertheless, mythic story telling has continued to thrive, and today survives in fields like religion, literature, theatre, television and - most importantly for our purposes - the cinema.

Scotland has long been mythologised, both by native Scots and by non-Scots. The most common, traditional myths concerning Scotland have characterised it as place that is primal, mysterious and earthy; a setting rooted in unique geography, people and legends. Medieval castles, bagpipes, whisky, haggis, kilted highland warriors and the Loch Ness Monster are the sorts of images that immediately come to mind in this regard. In numerous motion pictures released up to the present, traces of these mythic images still remain, and thus we find a Scotland that is imagined as a place set apart from the rest of the world by a distinctive collection of people, artefacts, practices and ways of life. In film, this characterisation has commonly been reified as a place inhabited by 'hard men' steeped in a history tying them to their soil, their families and their past. These hard Scotsmen are independent, passionate, sentimental and resistant to the encroachment of the modern 'civilised' world. The myths of Tartanry (emphasising the noble and heroic image of the highland warrior), Kailyard (emphasising the view of Scotland as a place made up of tight knit, traditional communities), and Clydesideism (emphasising the urban, often violent, face of Scotland) are three related aspects of this general mythic vision that are repeatedly drawn upon in the cinema.

These traditional myths have been the subjects of much criticism, and there is no doubt that they all represent stereotypical views of Scotland. In this literal sense, they all are certainly false portrayals. Yet, the general importance of myths, as already noted, does not lie in their literal falsehood, but in their symbolic truth. While we can acknowledge the literal falsehoods contained in traditional Scottish myths, there is also much of value to be gained by dispassionately understanding the symbolic meaning of their imagery as indicative of how Scotland is conceptualised by 
filmmakers and the viewing public. In this regard, I agree with David Martin-Jones' observation that Scottish myths need not be completely condemned, but 'may be productively considered as being both [positive and negative, op.a.] at the same time' (2010, p. 223).

Ever since Plato, thinkers have been concerned with the ways in which media images influence public perceptions of the world and of other people. Plato recognised that such images potentially can act as conduits for the Truth, but due to his commitment to a mimetic theory of art he also remained very critical of works produced by artists that were unrealistic, worrying that they would act as distractions from the 'real' world (1997b, 514a - 518e). Many contemporary critics of Scottish cinematic myths seem to carry this Platonic perspective into the present when they express indignation at films offering what they see as inaccurate depictions of Scotland, its people and their ways of life. But if the purpose of mythic stories is to express symbolic or allegorical truths, then it may be productive if we disengage ourselves from Plato's mimetic perspective on art, keeping in mind that mythic imagery does something more complicated than merely imitating the world around us. In doing this we can avoid getting entangled in discussions concerning the ways that cinematic images of Scotland lack correspondence to objective reality. Instead, we can raise the question of what the very idea of Scotland means to the people who are involved in mythmaking. Rather than searching for some sort of objective collection of things 'out there' - such as premodern communities, kilts or 'hard men' - that somehow correspond, or fail to correspond, to an objective state of affairs, we can instead examine the meaning of Scotland as a phenomenon, treating such images as manifestations of more fundamental patterns of thinking.

Cinematic representations drawing on Kailyard, Tartanry and Clydesideism tend to convey a sense of Scotland as a place that is distinct from the rest of the world. They highlight Scotland as a unique kind of location, thus encouraging audiences to consider dramas that take place there as expressive of regional realities not indicative of the experiences of humanity as a whole. On the one hand, this emphasis on Scottish uniqueness may be helpful in many ways to develop and solidify a national identity. After all, in order to understand ones' self as a 'people,' there must be some stable cultural characteristics that are shared by members of the community, distinguishing them as different from others. However, at the same time that an emphasis on unique 
characteristics can help to solidify distinctive identities, it also can serve to alienate and separate people, making them think of others as fundamentally different when in fact, essentially, they are more alike than they initially seem.

\section{The M yth of Scotland as Nowhere in Particular}

Currently, we are in the midst of a new mythic upsurge that expresses yet another facet of truth about Scotland. Rather than focusing on Scotland's uniqueness, this latest form of cinematic depiction emphasises the ways that Scotland is the same as other places in the world. In this, we find that particular, exotic things about Scotland are no longer so insistently foregrounded as fixations for audience entertainment. Rather, Scotland is offered as a more or less blank canvas against which filmmakers and audiences are invited to project their own aspirations, fears, concerns and interests. This portrayal of Scotland as 'nowhere in particular' serves to solidify the idea of Scotland as a part of the world community; a place much like any other where human beings are born, live, struggle and die. It is a depiction of Scotland increasingly stripped of its exoticism and uniqueness, making it appear at times as indistinguishable from anywhere else.

This has occurred in two related ways. First, there are films such as Prometheus, Perfect Sense, and Under The Skin. These films involve storylines that, while they do take place in Scotland, do not require the country as a setting. Second, there are films such as The Dark Knight Rises, Cloud Atlas, and World War Z. These movies, while being filmed (at least partly) in Scotland, nevertheless have plots that do not involve Scotland. Scottish locations, in this second group of movies, act as stand-ins for locations in other cities and places.

The first group of films - which I shall refer to as incomplete examples of the myth of Scotland as nowhere in particular - represent an initial step in the direction of the full obliteration of Scottish distinctiveness. These films, while they tell stories not tied to Scotland, still make a point of identifying their Scottish settings, retaining traces of past mythology. In this regard, they are not as successful in perfectly evoking the myth as is the second group of films. This second group - which I shall refer to as completed examples of the myth of Scotland as nowhere in particular take the final step in the direction of showing Scotland as nothing more than a blank 
backdrop containing no peculiar or unique characteristics of its own at all. Here we find 'Scotland' receding almost completely into the background and becoming indistinguishable from other locations such as Philadelphia, San Francisco, or the airspace above some anonymous, rural location. What this completed version of the myth accomplishes is, on the one hand, to efface Scotland's uniqueness while, on the other, to emphasise its likeness to other places. As with the more traditional myths mentioned earlier, this has both positive and negative implications. In becoming 'nowhere in particular,' Scotland certainly loses its own distinctive character; but it also gains status as a place on a par with a whole host of major world locations. As such, it becomes a site where universal human truths may be revealed rather than simply a setting where regional dramas are enacted.

We can see the differences between the incomplete and the completed versions of this myth clearly by comparing the opening sequences from Prometheus and The Dark Knight Rises, both major Hollywood movies released in 2012. Neither of these films have plots that involve Scotland or Scottish culture in any essential way. Prometheus is a science fiction tale that, while mostly set on a distant planet, begins on the Isle of Skye, while The Dark Knight Rises is an instalment in the Batman franchise that mostly takes place in Gotham City, but which begins on a plane in the skies north of Inverness.

The opening scenes from Prometheus are an example of the incomplete depiction of Scotland as nowhere in particular. Here, the Scottish location is explicitly announced with titles printed across the screen reading 'Isle of Skye - Scotland 2089.' A rock formation called the Old Man of Storr is prominently on display, marking this location as both picturesque and awe inspiring. Two archeologists (Noomi Rapace and Logan Marshall-Green) scamper across the green, rugged and exotic landscape, and proceed into a cave to investigate a painting that shows a humanoid figure pointing to the stars. The significance of this painting is later revealed when the two explorers explain to the crew of the spaceship Prometheus that the same sorts of images have been discovered in various ancient locations around the globe. They take this as an indication that the picture is in fact a map showing the way to some mysterious, far-off planet that holds the promise of revealing humankind's origin.

Nothing about this story requires that the opening should take place in a specifically Scottish setting. All that it requires is some sort of exotic, mysterious 
location with an ancient feel; and this is precisely the purpose served by situating this opening scene in the Scottish countryside. It is indicative of the general sort of place where archeological discoveries are made, and so the exotic and premodern mythos of Scotland is purposefully evoked. The date stamp '2089,' however, places the action in the far future, serving further to accentuate how removed the scene is from our own present-day experience. The landscape is thus presented as ambiguously exotic: it is both ancient and futuristic all at once. By existing in both the ancient past and the far future, it evokes a sense of timelessness. Later in the film, the Scottish cave painting is placed within the context of similar discoveries from other world locations, all of which are likewise ancient and exotic. We see artefacts from ancient Egyptian, Mayan, Sumerian, Babylonian, Hittite and Hawaiian cultures. These are all civilisations to which we look for our origins, and yet they have declined and been replaced by modern societies. Scotland, is one among many locations in the world where ancient cultures and peoples once existed; a place where the cycles of history have played out and where modern humans can still discover the traces of these cycles. This is how we find in Prometheus an incomplete manifestation of the myth of Scotland as nowhere in particular. In this film the Scottish landscape is identified, but only insofar as it is generally symbolic of many places where ancient peoples lived and died and where their artefacts continue to be found undisturbed and intact. In this way, while Scotland is still somewhere, it is not somewhere unique.

Compare this to the opening scenes of The Dark Knight Rises, a film that begins aboard an American airplane in which CIA agents are interrogating suspected terrorists. As the plane flies over an anonymous landscape of green hills and lakes, the plane is hijacked and destroyed by Batman's (Christian Bale) arch-enemy Bane (Tom Hardy) and his henchmen, who then proceed to try and take over Gotham City. In this opening scene, there is no indication that the landscape above which the drama plays out is the highlands of Scotland. As in Prometheus, the opening of this film could have transpired in any number of places, but unlike in Prometheus, there are no attempts by the filmmakers to establish by means of screen titles or dialogue where in the world the action really is occurring. This is because in The Dark Knight Rises there is no need to draw upon the mythos of any particular place. The drama that is the focus of the film is absolutely divorced from time and location in a way that the drama in Prometheus is not. Batman and his adversaries live in a fantasy world that 
truly is nowhere at no time. The effect produced is made possible by the fact that in the absence of any indicators concerning its real identity, the rural landscape of Scotland is devoid of iconic or easily recognisable landmarks that could distract audiences from the timeless and placeless nature of the fantasy world in which the characters operate. If Mount Fuji, Mount Kilamanjaro or Niagara Falls were to pop into view during the course of Bane's battle with the CIA agents, audiences would be yanked out of their illusion and thrust into a distracting setting of familiar, real world markers. The action would cease to be the only point of focus, and this is not what is called for. Rather, the action requires a geography that does not call attention to itself. In the world of Batman, the landscape acts as raw material against which epic, fantasy battles play out. It is nowhere in particular, and here we see the countryside of Scotland utilised in order to evoke this mythos. By receding completely into the background, Scotland ceases to call attention to itself at all, perfecting its purpose as a clearing, a space that is nowhere and nothing but a location for action.

\section{The Philosophical Significance of the Myth}

So what is the philosophical significance of the myth of Scotland as nowhere in particular and what does it tell us about how the idea of Scotland has evolved in present times? In order to explore this question, we need to understand the ways in which a work of art evokes, rather than imitates, a world. We can find guidance in this direction from Martin Heidegger, in particular from his essay 'The Origin of the Work of Art,' which focuses on how works of art provide sites within which Being itself is revealed. This will further illuminate the meaning of Scotland as a location in such recent films as Perfect Sense, Under the Skin, World War Z and Cloud Atlas.

According to Heidegger, 'All [artworks] have this thingly character,' however, 'the artwork is something else over and above the thingly element' (1993, p. 145). In this, he highlights the symbolic, rather than the imitative, nature of art. Artworks certainly must exist as objects, yet the function of an artistic object is to 'manifest something other; it is an allegory' (1993, p. 145). When viewing an artwork, the minds of an audience are drawn to something beyond the visible, tangible artefact and toward the meanings that the artefact makes present. In this sense, the work itself acts as a point of focus that gathers together and embodies some sort of significance. This 
significance, according to Heidegger, does not consist of the mimicry of objectively present things, but is best understood as an of upsurge of Truth that constitutes the evocation of a 'world.' He uses the example of a pair of peasant shoes painted by Van Gogh to illustrate the point (Van Gogh 1886). The artistry of Van Gogh's painting does not lie in the materials or the color or the structure of the shoes themselves, but rather in 'the dark opening of the worn insides of the shoes' (1993, p. 159), which reveal the whole world of the peasant's toil and labour; something which itself is not present to our senses. The image of the shoes only offers a site or a location within which we can find suggestions of the cycles and regularities that constituted the peasant's daily existence. What matters here is not how accurately the shoes are depicted in an objective, technical sense. What matters is how well the image of the shoes reveals and makes way for the peasant's unseen world of labour. Ultimately, any work of art 'holds open the open region of the world' in order to 'set forth the earth' (1993, p. 170). By this Heidegger means that the purpose of art is to offer a space within which particular manifestations of Being (things) can be displayed. But as an artwork opens up a space, it also at the same time must close it down by means of the depiction of particular objects. In so doing, it both reveals and conceals possibilities simultaneously. The space opened up by art reveals how particular objects may become manifest, and yet in their manifestation, particular objects crowd out the possibility for the appearance of other objects. According to Heidegger, this is the same sort of dynamic that we see at work in the world as a whole, and thus through art we are given the opportunity to behold an aspect of the rhythms of reality itself.

This Heideggerian perspective offers insight into what is significant about the myth of Scotland as nowhere in particular. We could say that movies evoking this myth strive to clear away, more or less completely, distracting 'things' (like kilts, haggises, 'hard men' and whisky) in order to evoke the pure openness of Being. The conundrum of course is that in striving toward this openness, filmmakers have to use something in order to coax this nothingness out of hiding, and yet the moment that something makes an appearance, the pure openness of Being itself is once again concealed. In trying to clear away distinctively Scottish symbols, then, something else must inevitably rush in to fill the space. 


\section{Incomplete Evocations of the Myth in Perfect Senseand Under the Skin}

We can see this conundrum enacted in Perfect Sense, one of the recent crop of Scottish films evoking the (incomplete) myth of Scotland as nowhere in particular. Set in Glasgow, this film tells the story of a love affair between Michael (Ewan McGregor), a chef at a trendy restaurant, and Susan (Eva Green), a scientist who is tracking the expansion of a worldwide epidemic that robs people of their senses one by one. The twin themes of love and disease work to place the subject matter on a universal, human level that transcends any particular time or place. All people, regardless of national origin, are concerned with such experiences, of course, and the Glaswegian setting, though it is alluded to, is not a necessary component of the film's message. In fact, throughout the film we are reminded that the drama playing out within this particular city is merely part of a worldwide pandemic afflicting all of humanity. As in Prometheus, Scotland is simply treated as one place among many others. The story is not really about Scotland, but something universal to the human condition.

Perfect Sense goes further, however, in suggesting that the loss of attachment to particular senses may actually grant humans access to the infinity of Being itself. Preceding the loss of each sense, the film's characters experience emotional outbursts, which soon evaporate to be replaced with peaceful acquiescence. First smell is lost, then taste, then hearing and finally sight. At each step of the process, it seems initially that civilisation might collapse. Nonetheless, as the narrator informs us, 'Life goes on.' People adapt to living with decreasing sensory input, testing the boundaries of how many things can be subtracted before the world disintegrates altogether. In the final moments of the film the two lovers embrace and everything goes black as they lose their ability to see. With the evaporation of all sensible 'things,' the movie ends, but we are left to consider that the most important and enduring human reality still remains. This fundamental reality is not a thing or an object at all, but the bonding power of love, which was previously obscured by all of the world's particular entanglements and distractions. In this film, it is the emptiness of the blank screen that finally evokes the true message. Take away all things and Being still remains, which is finally revealed as pure, sublime, loving and all embracing nothingness. 
Perfect Sense strives to demonstrate that we should not equate reality with the sum total of 'things' that appear in our environment. As Heidegger suggests, Being is not a thing, but the condition that allows for the emergence of things, and while the evocation of a world is made possible through the presence of tangible sensory objects, the world thus evoked is not reducible to those objects. Objects are merely conduits through which the nothingness of Being 'speaks.' In this way, we can see that the Glaswegian setting of Perfect Sense acts merely as a site that allows this more universal, philosophical message to be conveyed. The irony, of course, is that in order to make any film, some sort of imagery is necessary, and yet the imagery itself is not the most important focus. What is most important is to understand that as sensory objects progressively disappear, the underlying reality of Being remains. And while the ultimate point of the film is actually realised at the end when everything goes black, this point could not be made without the previous unfolding of sensory events. We need the unfolding events to appear in contrast to the nothingness of the film's conclusion in order to even have a drama in the first place. If the film consisted of nothing but blackness and void, its message would fail. The void would have no objects through which to 'speak.' It would remain mute. In this way, Perfect Sense does offer a completed evocation of the myth of Scotland as nowhere in particular; but only in its final moments before the roll of the credits when everything fades into nothingness. It is then that the city of Glasgow fully recedes, making way for the clearing that is pure Being itself.

Glasgow reappears to offer an incomplete evocation of the myth of Scotland as nowhere in particular in Under the Skin, a film focusing on a space alien (Scarlett Johansson) who trolls the streets of Glasgow in search of human victims. In this film, the specific choice of Glasgow as a location for the action is, once again, unimportant to the film's narrative. ${ }^{2}$ As in Perfect Sense, we know that this is Glasgow, partly because of the broad accents of the people encountered by the main character during her journey through the streets. These accents, however, do not really serve to set the story in a particular time and place so much as to highlight the generally strange, vaguely threatening and exotic nature of the location as experienced from the perspective of the main character. As with the Scottish imagery at the beginning of Prometheus, the specific identity of these accents is not really what is significant; rather they act as a particular kind of marker - a 'thing' - highlighting this as a place 
foreign and unusual. This is a feeling reinforced by the disorienting and surreal nature of some of the film's imagery, such as the scenes where characters are lured toward, and suspended in, a weird pool of black ooze whose place and location remains puzzling. Traces of the mysterious and exotic mythos of Scotland, thus, are still present, but here they are used here in order to channel a more general mood of dislocation and 'alien'ation.

In Under the Skin, the streets of Glasgow could be anywhere that people are difficult to understand and the territory is unfamiliar. This could be Boston or Bangkok; Moscow or Madrid. What is evoked is not uniquely Scottish, but a universal sense of displacement, or what Heidegger terms 'homelessness' (1993, p. 363). Part of this universal, human condition consists of being 'thrown' into a world not of our own making (Heidegger 1996, p. 127). In Under the Skin, this condition is evoked by depicting a character who has been uprooted and thrust into a city - and a skin - that is not her own. She is an alien among aliens. What is symbolised through the film's imagery is the experience of an unsettling estrangement from Being itself; an absence of any sense of belonging or connection. This is clearly articulated at one point by a Czech tourist who tells the main character that the reason he came to Scotland was precisely, 'Because it's nowhere.' He didn't come to hear bagpipes, eat haggis or to see castles. He came to lose himself in a strange, unfamiliar and foreign land. This landscape acts merely as a backdrop against which a universal drama of loneliness and dislocation plays out.

When the action in Under The Skin moves to the Scottish countryside, the backdrop becomes even more nondescript than were the dark, shadowy and disorienting streets of Glasgow. Here, the alien character makes her way along trails and through woods that give no indication of their location. The people, buildings and streets of the city are cleared away to make room for unremarkable trees and bushes. Now the main character really is lost, wandering in the middle of nowhere, headed no place in particular. She ultimately meets her doom in a snow-covered field, a clearing in the woods that serves to suggest the openness of Being itself. It is here where she is exposed for what she really is: an imposter, an interloper upon this landscape who has been pretending to be human. This character, who was portrayed previously as an aggressive, otherworldly predator, is transformed into a vulnerable victim for whom we now feel sympathy. Her skin is torn away and she is exposed as a mortal, death- 
bound creature existing beneath the open skies and groveling upon the surface of the earth. Here we find a powerful evocation of the universal existential condition of all mortal creatures. The closing scene of the film, which focuses on snowflakes filling an empty sky, parallels the final blackness of Perfect Sense. Each flake, unique and fragile, passes by, eventually to melt away, while the open sky, the backdrop of Being, remains.

\section{Completed Evocations of the Myth in Cloud Atlasand World War Z}

The effacement of identifiably Scottish objects, landmarks and locations is carried out in an even more complete but less philosophically self-conscious manner in two Hollywood films: Cloud Atlas and World War Z. Like Perfect Sense and the first part of Under the Skin, and in contrast to Prometheus and The Dark Knight Rises, in these films it is urban, rather than rural, locations that act as backdrops to the storytelling. Both films are notable in their use of Glasgow as a set, which in both cases acts as a stand-in for other, U.S. cities. In the case of Cloud Atlas, Glasgow's financial district is used to depict the streets of 1970s San Francisco, while in World War Z, Glasgow's George Square acts as a backdrop to a zombie invasion that is supposed to be taking place in Philadelphia. In neither film are Glaswegian locations ever identified. Instead, they fade into the background, providing only the space within which the action unfolds. As in The Dark Knight Rises, where the nondescript nature of the rural backdrop allowed for the emergence of a fantasy world, so too in Cloud Atlas and World War Z, the fantasy worlds that are evoked are made possible by the nondescript urban backdrop of Glasgow. What is brought into existence are generic, urban spaces, neither uniquely Scottish nor American, that exist nowhere in reality, and so serve perfectly to support fantastic narratives that, likewise, share no connection to real-life events.

By clearing away any distinctive Scottish markers, these completed examples of the myth succeed in evoking fantasy worlds by using a collection of buildings, streets and other 'things' as raw material. It is interesting to note that in these two films, the city of Glasgow serves as a stand-in for otherwise very different sorts of U.S. cities: one from the East Coast and the other from the West. It is significant that both Philadelphia and San Francisco themselves are capable of being evoked in this 
way. This may suggest that like Glasgow, these two cities could be anywhere, and that what is most important about them is not necessarily found in their locations or cultures. What is important is that they are sites in which any type of human action might take place. They are world cities, like New York City (which Glasgow also stood in for in The House of Mirth), embodying something more than simply a collection of 'things.' They embody the idea of the metropolis within which many different sorts of human, not just American or Scottish, dramas unfold. Insofar as the specifically Scottish locations in Cloud Atlas and World War $Z$ fade into the background, then, we seem to find an almost perfect evocation of the myth of Scotland as nowhere in particular. And yet, insofar as the stories told in these films still require some sort of city as a setting, the pure openness of Being remains covered over, even as it strains to 'speak' through images of buildings, roads, cars and sidewalks.

\section{Conclusion}

Myths are more than just falsehoods. They indicate recurrent and meaningful patterns in collective human thinking. This article has attempted to identify and describe some basic features of an emerging myth that I have called the myth of Scotland as nowhere in particular, indicating how it signals a new pattern of thinking about Scotland and its place within the world. This has involved a reassessment of the nature of Scottish myth-making and the introduction of a perspective less inspired by Platonic assumptions than has normally been the case. By understanding myths as stories whose function is to symbolically represent, rather than to literally reflect, reality, we have positioned ourselves to better understand how this new myth indicates an additional facet of truth about the very idea of Scotland. In it, we see how filmmakers and audiences have increasingly come to conceive of Scotland as a location capable of evoking worlds that are not distinctively Scottish at all, but which could be any place, anywhere.

Traditionally, Scotland has been used as a setting that evokes worlds through displays of stereotyped imagery, but in such recent films as Prometheus, The Dark Knight Rises, Perfect Sense, Under the Skin, Cloud Atlas and World War Z we have encountered something new. In these recent films, the rural and urban landscapes of 
Scotland are used - more perfectly in some films than in others - to provide a space within which dramas having very little (if anything) to do with Scotland unfold. In Prometheus, Perfect Sense and Under the Skin we see the incomplete effacement of Scottish 'things,' while in The Dark Knight Rises, Cloud Atlas and World War Z there is a more complete accomplishment of this removal, which then makes way for nonScottish fantasy worlds of superheroes, supervillains, foreign cities and zombies. The resulting films thus appeal to an experience that is more than just regionally significant. It is an experience that is transnational, transcultural and, insofar as Being itself is evoked, perhaps even metaphysical in scope.

\section{Endnotes}

\footnotetext{
${ }^{1}$ For some interesting insights into the attitudes of Scottish audiences toward big budget, Hollywood films using Scotland as a backdrop see Simon Brown's interview with Alice Black in this issue.

${ }^{2}$ The book by Michael Faber upon which the movie is based, in fact, takes place in the highlands of Scotland, not in Glasgow itself.
}

\section{References}

BALKIND, N. 2013. 'Glasgow: Hollywood Film Set'. In: BALKIND, N. ed. World Film Locations: Glasgow. Chicago: University of Chicago Press, pp. 92 - 93.

BROWN, S. 2011. “"Anywhere but Scotland?” Transnationalism and New Scottish Cinema'. International Journal of Scottish Theatre and Screen [online] 4(1). Available from: http://journals.qmu.ac.uk/index.php/IJOSTS/article/view/109 [Accessed January 17 2014].

CAMPBELL, J. 2008. The Hero With a Thousand Faces. Novato: New World Library.

CRAIG, C. 1982. 'Myths Against History: Tartanry and Kailyard in 19th-Century Scottish Literature'. In: MCARTHUR, C. ed. Scotch Reels: Scotland in Cinema and Television. London: BFI, pp. 7 - 15.

Cloud Atlas. 2013. Directed by Lana Wachowski, Tom Tykwer and Andy Wachowski. US: Cloud Atlas Productions [DVD].

The Dark Knight Rises. 2012. Directed by Christopher Nolan. US: Warner Brothers [DVD].

FABER, M. 2000. Under the Skin. Orlando: Harvest Books.

GOODE, I. 2007. 'Different Trajectories: Europe and Scotland in Recent Scottish Cinema'. PORTAL Journal of Multidisciplinary International Studies [online], 4(2) July. Available 
from: http://epress.lib.uts.edu.au/journals/index.php/portal/article/view/420 [Accessed January 17 2014]

HARDY, F. 1990. Scotland in Film. Edinburgh: Edinburgh University Press.

HEIDEGGER, M. 1993. 'The Origin of the Work of Art'. In: FARRELL KRELL, D. ed. Martin Heidegger: Basic Writings. San Francisco: Harper Collins, pp. 139 - 206.

HEIDEGGER, M. 1993. 'Building Dwelling Thinking'. In: FARRELL KRELL, D. ed. Martin Heidegger: Basic Writings. San Francisco: Harper Collins, pp. 343 - 363.

HEIDEGGER, M. 1996. Being and Time. Albany: SUNY Press.

HERBERT, Daniel. 2009. 'Trading Spaces: Transnational Dislocations in Insomnia/Insomnia and Ju-on/The Grudge'. In: LUKAS, S. and MARMYSZ, J. eds. Fear, Cultural Anxiety, and Transformation: Horror, Science Fiction and Fantasy Films Remade. Lanham: Lexington Books, pp. 143-164.

The House of Mirth. 2000. Directed by Terence Davies. UK: The Arts Council of England [DVD].

MARIN-JONES, D. 2010. Scotland: Global Cinema: Genres, Modes and Identities. Edinburgh: Edinburgh University Press.

MCARTHUR, C. 1982. 'Scotland and Cinema: The Iniquity of the Fathers'. In: MCARTHUR, C. ed. Scotch Reels: Scotland in Cinema and Television. London: BFI, pp. 40 69.

NEELY, S. 2008. 'Contemporary Scottish Cinema'. In: BLAIN, N. and HUTCHISON, D. eds. The Media in Scotland. Edinburgh: Edinburgh University Press, pp. 151- 165.

ORIA GOMEZ, B. 2008. 'Imagining Scotland: Local Hero (1983) and Kailyardism'. Barcelona English Language and Literature Studies [online] 17 Autumn. Available from: http://www.publicacions.ub.edu/revistes/bells17/ [Accessed January 18 2014].

Perfect Sense. 2011. Directed by David Mackenzie. UK: BBC Films [DVD].

PETRIE, D. 2000. Screening Scotland. London: BFI.

PLATO. 1997b. 'Republic'. In: COOPER, J. ed. Plato: Complete Works. Indianapolis/Cambridge: Hackett Publishing Company, pp. 971 - 1223.

Prometheus. 2012. Directed by Ridley Scott. US: 20th Century Fox [DVD].

ROYER, M. 2010. 'National Cinemas and Transnational Mappings: The Case of France'. Literature \& Aesthetics [online] 20(1) July. Available from: http://ojsprod.library.usyd.edu.au/index.php/LA/issue/view/334 [Accessed June 8 2014].

SCHORER, M. 1968. 'The Necessity of Myth'. In: MURRAY, H. ed. Myth and Mythmaking. Boston: Beacon Press, pp. 354-358. 
STREET, S. 2009. 'New Scottish Cinema as Trans-national Cinema'. In: MURRAY, J., FARLEY, F. and STONEMAN, R. eds. Scottish Cinema Now. Newcastle: Cambridge Scholars, pp. 139 - 152.

Under the Skin. 2013. Directed by Jonathan Glazer. UK: Film4.

VAN GOGH, V. 1886. A Pair of Shoes [oil on canvas] held at Van Gogh Museum, Amsterdam.

World War Z. 2013. Directed by Marc Forster. US: Paramount Pictures [DVD]. 